\title{
母および子めん羊の血清中コルチゾール濃度および $\operatorname{IgG}$ 濃度におよぼす早期離乳の影響
}

\author{
関根純二郎・小林かおり・金 海 - 大浦良三・菱沼 貢 \\ 鳥取大学農学部, 鳥取市 680
}

(1997 年 10 月 2 日受理)

\section{緒 言}

動物に説明不能な障害あるいは生産性低下を生 じるような外的環境要因がストレス要因と定義さ れている4)。動物のストレス要因については, 種々の研究が行われており, 家畜は常に広範囲な ストレスにさらされていることが知られてい る5)。これらストレスの要因としては, 時間的経 過の長さ（輸送あるいは離乳等）が関連する要 因 ${ }^{4)}$ および反復して加えられる外的刺激3)などが 知られている。さらに, 家畜において外的環境あ るいは管理作業などの要因によって生じる精神的 ストレスは, 動物の脳下垂体-副腎軸を活性化さ せ，免疫機能を低下させると報じられている ${ }^{2)}$ 。 サルにおいても生後 1 才未満の時期に, 10〜 14 日 間母親や仲間から隔離された体験をあつ個体は, 5 才時におけるコンカナバリン $\mathrm{A}$ 等に対するリ ンパ球幼若化反応が, 体験のないあのに比べて有 意に低下していたと報じられている7)。森山ら ${ }^{11)}$ は, 90 日齢で離乳した子めん羊において, 離乳直 後に血中コルチゾール濃度が増加する傾向を示し たことから，離乳がストレス因子となりうること を示唆した。子めん羊の離乳は, 動物の能力およ び経営の両面から見て, 3 4 力月龄が適当である といわれている8 が，この時期においてあ離乳が 子めん羊のストレス因子となる可能性がある。し たがって, 細胞性免疫を担う $\mathrm{T}$ リンパ球の介在を 必要とする B リンパ球からの IgG 分泌 ${ }^{12)}$ にも影 響をおよぼす可能性むある。
そこで, 本研究では, 哺乳期間を短縮して早期 に離乳した場合における母めん羊ならびに子めん 羊の血清中コルチゾール濃度ならびに血清中 $\mathrm{IgG}$ 濃度の変化から, 早期離乳が母めん羊ならびに子 めん羊のストレス因子となり得るか否かを評価す ることを目的とした。

\section{材料および方法}

\section{1. 供試動物}

鳥取大学農学部附属農場において生産されたコ リデールおよびサフォーク雑種めん羊の親子 7 組 を供試した。このうち, 母めん羊 4 頭（個体番号, $1,2,3,4$ 号) および子めん羊 4 頭 (10 우, $20 \sigma^{\nearrow}$, 30 ð, 40 フ号) の組を 3.5 力月齢で離乳し, 対照群 とした。早期離乳群は, 母めん羊 3 頭 (個体番号, $5 ， 6 ， 7$ 号）および双生産子を含む子めん羊 5 頭 (同, 50 ○フ, 60 우, 66 우, 70 우, 77 우) であった。

\section{2. 飼養管理}

両群とあ母めん羊は分婏まで群飼とし, 分婏後 は親子組を隣接するパドックに移し, 各組ごとに 飼養した。対照群は, 子めん羊が 3.5 力月㱓に なった時点で離乳した。早期離乳群は, 子めん羊 が 1.5 力月龄になった時点で離乳し, 離乳後は, 母および子めん羊をそれぞれ群飼した。飼料は, イタリアンライグラス乾草を自由採食させ，1 日 2 回朝夕にふすまを補給した。水および鉱塩む, 自由摂取させた。

子めん羊の生体重を, 出生時, 1.5 力月齢抢よび 3.5 カ月齢に測定した。

Jpn. J. Sheep Sci., $34:$ 8-13. 1997

Effect of early weaning on serum cortisol and serum IgG concentration of ewes and their lambs Junjiro Sekine, Kaori Kobayashi, Jin Hai, Ryozo OuRA and Mitsugu Hishinuma

Faculty of Agriculture, Tottori University, Tottori-shi 680 
3. 血中コルチゾール濃度および IgG 濃度の 測定

採血を実施するに当たり，めん羊におけるスト レス負荷試験1,9,10)による血中コルチゾール濃度 の経時的変化ならびに COPPINGER et al. . $^{3)}$ が示した コルチゾール濃度の増加により免疫機能が低下す るとした結果を参考とした。離乳後の血中コルチ ゾール濃度および血中 IgG 濃度の変化を検討す るため, 離乳当日を第 1 日目として以下のような 採血日程を設定した。離乳当日に，離乳 30 分前お よび 30 分後に, 母および子めん羊の頚静脈より 採血した。さらに離乳 2 日目, 3 日目, 6 日目， 1 週間目, 3 週間目および 6 週間目にも離乳後 30 分 と同時刻に採血を行った。

採取した血液は, $3,000 \mathrm{rpm}$ で 60 分間遠心分離 を行い，血清を分離してサンプルとした。血清サ ンプルは分析に供するまで $-80^{\circ} \mathrm{C}$ で凍結保存し た。コルチゾールの分析にはラジオイムノアッセ イ法（RIA 法）を，IgGの分析には一元放射免疫 拡散法（SRID 法）を用いて測定した。

\section{結果}

子めん羊の生体重を, 図 1 に示した。早期離乳 群の生体重は, 対照群に比べて個体によるばらつ きが大であったが，有意な違いは認められず，日

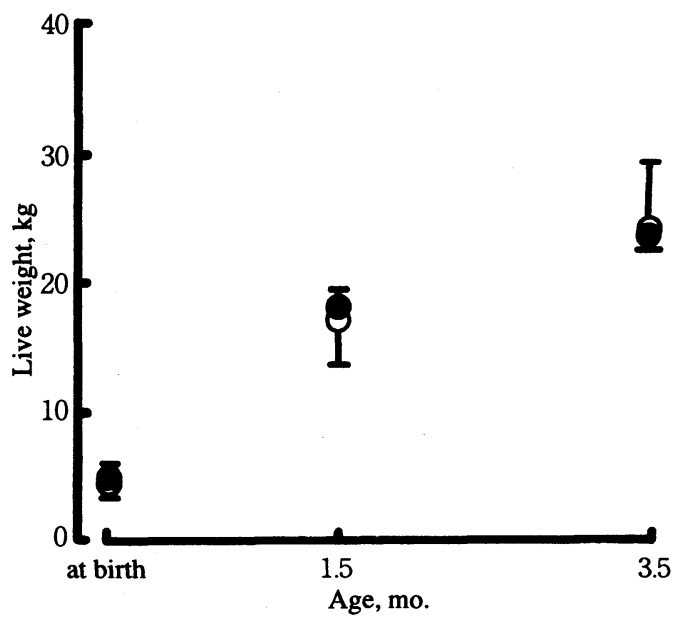

Fig. 1. Changes in live weight of lambs weaned at 1.5 ( $\bigcirc)$ or 3.5 (O) mo. of age.

Vertical lines show standard deviation.
増体量は, 両群とあに約 $0.2 \mathrm{~kg}$ であった。しか し, 1.5 力月齢以降の 2 力月間では, 対照群の 0.12 $\mathrm{kg} /$ day に対して早期離乳群では $0.09 \mathrm{~kg}$ とやや 低い值であった。

子めん羊の血清中コルチゾール濃度の変化を図 2 に示した。対照群および早期離乳群ともに，離 乳後の経過日数とともに血清中コルチゾール濃度 が低下する傾向は認められるものの, 有意な変化 ではなかった。両群の間にあコルチゾール濃度の 有意な違いは認められなかった。

母めん羊の血清中コルチゾール濃度の変化を図 3 に示した。早期離乳群では, 離乳前後およびそ の後のサンプル採取日による変化は認められな かった。対照群では, 離乳前より離乳後が有意に 低いコルチゾール濃度となった $(\mathrm{P}<0.01)$ 。それ 以降は, 多少のばらつきはあるが離乳前より低い 值で推移する傾向にあった。

子めん羊の血清中 IgG 濃度の変化を図 4 に示 した。対照群ではサンプル採取日による血清中

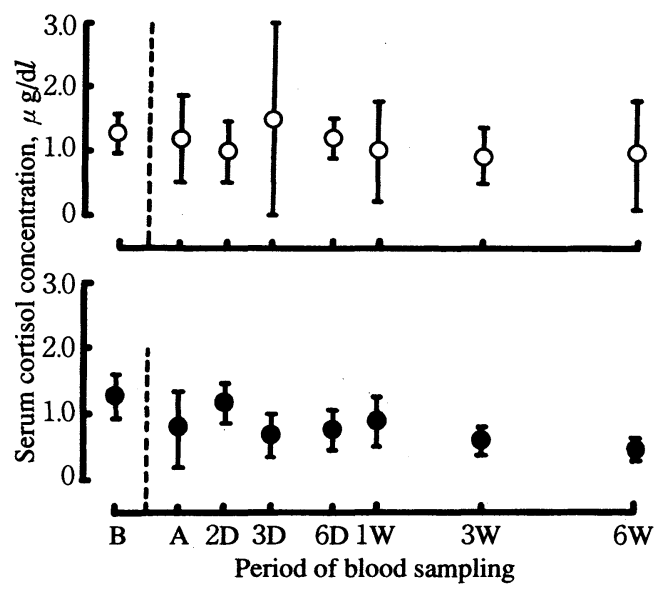

Fig. 2. Changes in serum cortisol concentration before and after weaning for lambs weaned at 1.5 ( $\bigcirc)$ or 3.5 mo. of age.

Vertical lines show standard deviation. The broken line shows weaning.

Abbreviated notations for period of blood sampling are as follows: $\mathrm{B}, 30$ min. before weaning; A, $30 \mathrm{~min}$. after weaning, $2 \mathrm{D}, 3 \mathrm{D}$ and $6 \mathrm{D}, 2 \mathrm{nd}, 3 \mathrm{rd}$ and 6 th day after weaning, respectively $; 1$ $\mathrm{W}, 3 \mathrm{~W}$ and $6 \mathrm{~W}, 1 \mathrm{st}, 3 \mathrm{rd}$ and 6 th week after weaning, respectively. 


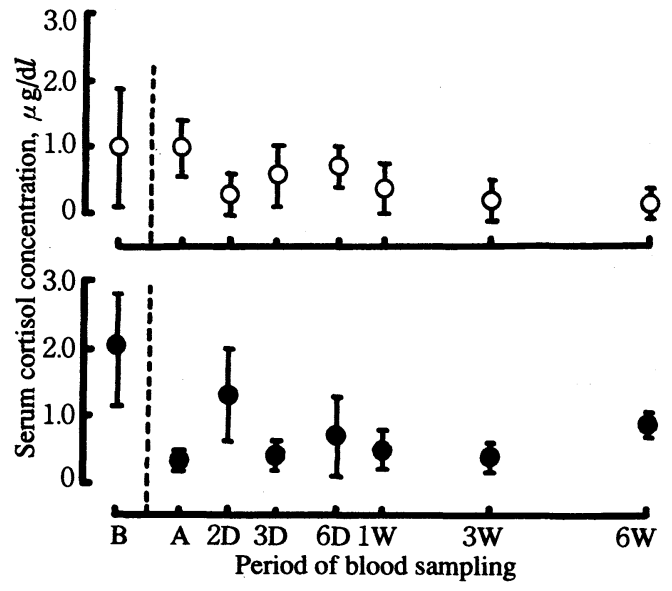

Fig. 3. Changes in serum cortisol concentration before and after weaning for ewes whose lambs weaned at 1.5 (O) or 3.5 (O) mo. of age.

Vertical lines show standard deviation. The broken line shows weaning.

Abbreviated notations for period of blood sampling are as follows: B, 30 min. before weaning; A, $30 \mathrm{~min}$. after weaning, $2 \mathrm{D}, 3 \mathrm{D}$ and $6 \mathrm{D}, 2 \mathrm{nd}$, 3rd and 6 th day after weaning, respectively ; 1 $\mathrm{W}, 3 \mathrm{~W}$ and $6 \mathrm{~W}, 1 \mathrm{st}$, 3rd and 6 th week after weaning, respectively.

IgG 濃度に有意な違いは認められなかった。早期 離乳群では, 離乳後 3 週間目までは有意な変化は 認められなかったが， 6 週間目では他のサンプル 採取日に比べ有意に高い值となった $(\mathrm{P}<0.01) 。$

母めん羊の血清中 IgG 濃度の变化を図 5 に示 した。両群とも, 血清中 IgG 濃度にサンプル採取 日による有意な違いは認められなかった。また， 対照群と早期離乳群との間にも有意な違いは認め られなかった。

$$
\text { 考察 }
$$

子めん羊を 90 日齢で離乳した場合, 母めん羊 を隔離する 30 分前より隔離した 30 分後で, 血清 中コルチゾール濃度が高くなる傾向が認められた ことから，離乳は大きなストレス要因ではない が, 何らかの影響があることが示唆されてい た ${ }^{11)}$ 。しかし，本試験の結果では，対照群と早期 離乳群の間で血清中コルチゾール濃度に有意な違

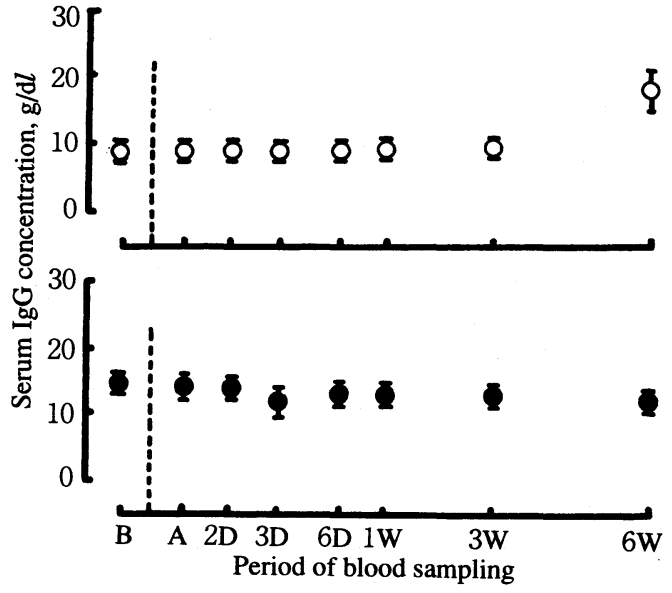

Fig. 4. Changes in serum IgG concentration before and after weaning for lambs weaned at $1.5(\mathrm{O})$ or 3.5 (O) mo. of age.

Vertical lines show standard deviation. The broken line shows weaning.

Abbreviated notations for period of blood sampling are as follows: $\mathrm{B}, 30$ min. before weaning; $A, 30$ min. after weaning, $2 \mathrm{D}, 3 \mathrm{D}$ and $6 \mathrm{D}, 2 \mathrm{nd}, 3 \mathrm{rd}$ and 6 th day after weaning, respectively ; 1 $\mathrm{W}, 3 \mathrm{~W}$ and $6 \mathrm{~W}, 1 \mathrm{st}, 3 \mathrm{rd}$ and $6 \mathrm{th}$ week after weaning, respectively.

いが認められず，両群とあサンプル採取日による 有意な違いも認められなかった。さらに，血清中 $\mathrm{IgG}$ 濃度も離乳期前後において有意な変化が認め られなかった。子めん羊は, 物理的拘束あるいは 隔離などの負荷により，1 時間以内に血清中コル チゾール濃度が急速に増加する ${ }^{1,9,10)}$ が, 物理的な 負荷の加わらない条件では，血清中コルチゾール 濃度に変化を及ぼすほどの要因にはなっていない と推測される。したがって, 1.5 力月齢の早期離乳 は，子めん羊が生理的に反応するほど大きなスト レス因子とはなっていないであろうと推察され る。

早期離乳群では, 血清中 IgG 濃度が, 離乳 6 週 間目に $18.7 \mathrm{~g} / l$ へ有意に増加していた。子めん羊 では, 生後約 3 力月で成めん羊之同様な免疫機能 が作動するようになる ${ }^{6)}$ とされている。また，成 めん羊の正常值の範囲は, $17 \sim 20 \mathrm{~g} / l$ である ${ }^{13)}$ 。 早期離乳群では, 離乳 6 週間目がおおよそこの時 


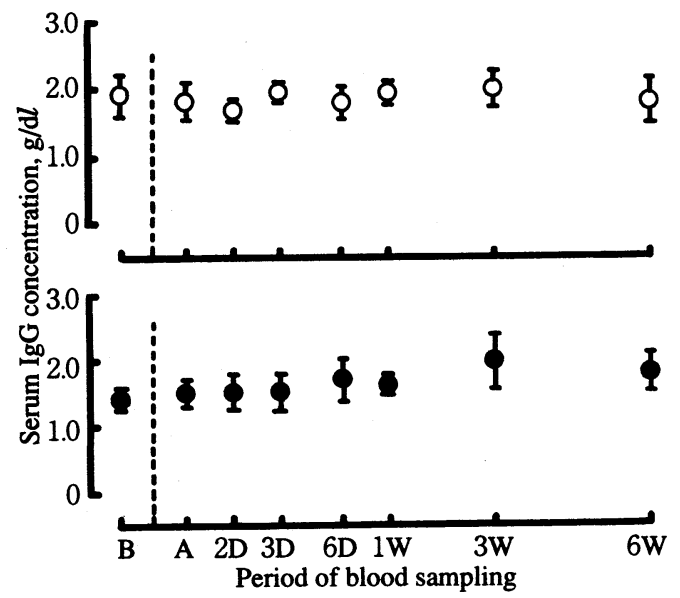

Fig. 5. Changes in serum IgG concentration before and after weaning for ewes whose lambs weaned at 1.5 ( $\bigcirc$ ) or 3.5 (O) mo. of age.

Vertical lines show standard deviation. The broken line shows weaning.

Abbreviated notations for period of blood sampling are as follows: $\mathrm{B}, 30$ min. before weaning; A, $30 \mathrm{~min}$. after weaning, $2 \mathrm{D}, 3 \mathrm{D}$ and $6 \mathrm{D}, 2 \mathrm{nd}$, 3rd and 6 th day after weaning, respectively ; 1 $\mathrm{W}, 3 \mathrm{~W}$ and $6 \mathrm{~W}, 1 \mathrm{st}$, 3rd and 6 th week after weaning, respectively.

期に相当するむのであり, 濃度も正常值の範囲内 にあることから, 離乳 6 週間目の濃度変化は免疫 機能の成熟によるものであり，離乳の影響が現れ たものではないと判断した。

しかし, 早期離乳群では, 体重のばらつきが大 きく, 1.5 力月齢以降の 2 力月間では, 日増体量が 対照群の $0.12 \mathrm{~kg} /$ day に対して $0.09 \mathrm{~kg}$ とやや低 い値であったことから，日常の飼養管理に注意を 要するものと考えられる。

早期離乳群の母めん羊では, 離乳期前後におけ る血清中コルチゾールならびに IgG 濃度に有意 な変化が認められなかったことから，1.5力月齢 離乳は，母めん羊の血中指標に影響が現れるほど のストレス因子とはなっていないと推察される。

対照群の母めん羊では，離乳前より離乳後が有 意に低いコルチゾール濃度となり，その後の水準 あ低く推移していた。したがって, 離乳直前では 哺乳期間が長いことによる慢性的なストレス状態
から離乳により解除されたとの推測も成り立つと 考えられる。しかし, 血清中 IgG 濃度は, 離乳後 の時間の経過とともに増加する傾向は示すむのの 有意な違いは認められなかった。また，採血時の 一時的な拘束が物理的ストレスとして影響したと あ考えられる。さらに, 本研究では, 哺乳期間中 の測定を実施していないので, 本研究の結果から は, その詳細についての説明は不可能である。

以上のことから, 本研究では, 母めん羊ならび に子めん羊の血清中コルチゾール濃度および血清 中 IgG 濃度の変化により評価すれば, 1.5 力月齢 離乳が母めん羊および子めん羊のストレス因子と はならないであろうと結論された。

$$
\text { 要 約 }
$$

1.5 力月齢の早期離乳前後における母めん羊な らびに子めん羊の血清中コルチゾール濃度および 血清中 IgG 濃度の変化から, 早期離乳がストレス の要因となり得るか否かを評価する目的で試験を 実施した。 4 組の母子を 3.5 力月龄 (対照群) で, 3 組の母子を 1.5 力月齢 (早期離乳群) で離乳し, 離乳前後 30 分抒よび離乳後 $2,3,6$ 日目，1，3， 6 週間目に血清中コルチゾールおよび $\operatorname{IgG}$ 濃度を 測定し, 以下の結果を得た。

1）子めん羊では，対照群と早期離乳群の間に は血清中コルチゾールおよび IgG 濃度に有意な 違いは認められなかった。早期離乳群では血清中 IgG 濃度が離乳後 6 週間目に有意に高くなった が，免疫機能の作動の結果であると推察された。 それ以外は両群とも, 離乳後における変化は認め られなかった。

2）母めん羊であ, 対照群と早期離乳群の間に は血清中コルチゾールおよび IgG 濃度に有意な 違いは認められなかった。対照群では, 血清中コ ルチゾール濃度が離乳前で離乳直後より有意に高 い值となったが，その理由は明らかではなかっ た。

3）本研究では，母ならびに子めん羊の血清中 コルチゾール濃度および血清中 IgG 濃度の変化 からは，早期離乳がストレスの要因とならないで あろうと結論された。 


\section{文献}

1) Apple, J.K., J.E. Minton, K.M. PARsons and J.A. UNRUH, Influence of repeated restraint and isolation stress and electrolyte administration on pituitary-adrenal secretions, electrolyte, and other blood constituents of sheep. J. Anim. Sci., 71 : 71-77. 1993.

2) Collins, M.T. and F. Suarez-Guemes, Effect of hydrocortizone on circulating lymphocyte numbers and their mitogen-induced blastogenesis in lambs. Am. J. Vet. Res., 46 : 836-840. 1985.

3) Coppinger, T.R., J.E. Minton, P.G. Reddy and F. BLECHA, Repeated restraint and isolation stress in lambs increases pituitary-adrenal secretions and reduces cell-mediated immunity. $J$. Anim. Sci., 69 : 2802-2814. 1991.

4) Danzter, R. and P. Mormede, Stress in farm animals : A need for reevaluation. J. Anim. Sci., 57 : 6-18. 1983.

5) Friend, T.D., Response of animals to stress ; Behavioral aspects of stress. J. Dairy Sci., 74 : 292-303. 1991.

6）伊沢久夫・清水悠紀臣 - 内貴正治 - 見上 虎, 獣 医学領域における免疫学. 299. 近代出版. 東京.
1981.

7) Landenslager, M., J.P. CaPitanio and M. Reite, Possible effects of early separation experiences on subsequent immune function in adult Macaque monkeys. Am. J. Psychiatry, 142:862864. 1985.

8）三村 耕, 家畜行動学. 95-96. 養賢堂. 東京. 1988.

9) Minton, J.E. and F. Blecha, Effect of acute stressors on endocrinological and immunological functions in lambs, J. Anim. Sci., 68 : 31453151. 1990.

10） Minton, J.E., T.R. Coppinger, P.G. Reddy, W.C. DAvis and F. BLECHA, Repeated restraint and isolation stress alters adrenal and lymphocyte functions and some leucocyte differenciation antigens in lambs. J. Anim. Sci., 70 : 1126-1132. 1992.

11）森山知江子・H.E.M. カメル・金 海 ・大浦良 三・関根純二郎, 子めん羊の哺乳期および離乳期 前後における行動様式の変化. 日緬研会誌, 32 : 14-21. 1995.

12）大村 裕 - 掘 哲郎, 脳と免疫. 21. 共立出版. 東京. 1995.

13）友田 勇, 臨床血液化学検査. 298. 学悹社. 東京. 1992. 


\section{Summary}

Changes in serum cortisol and serum IgG concentration were determined in the course of weaning in 7 pairs of ewes and lambs to evaluate whether early weaning is a stressor for them. Weaning for 4 pairs was carried out at lamb' age of $3.5 \mathrm{mo}$. (control) and that for 3 pairs at lamb' age of $1.5 \mathrm{mo}$. (early weaned). Determinations of serum cortisol and serum IgG were done at $30 \mathrm{~min}$. before and after weaning, and thereafter, 2, 3, 6 days and 1, 3 and 6 weeks after weaning. Results were as follows : 1) For lambs, there were no significant differences in serum cortisol and IgG concentration between control and early weaned groups, and nor among periods for determination except for serum IgG at 6 weeks after weaning in early weaned lambs. This change was inferred to be caused by the establishment of immune system in early weaned lambs. 2) Ewes also showed no significant changes in serum cortisol and IgG concentration between groups and among periods except for serum cortisol concentration before weaning for ewes in control group. Results in the present study failed to explain the exact cause for this change. 3) From changes of serum cortisol and IgG concentration obtained in the present study, it is concluded that early weaning is not a stressor for ewes and lambs. 